\title{
Enhancing rice yield in acidic soil through liming and fertilizer management
}

\author{
Syeda Ariana Ferdous ${ }^{1}$, Mohammad Noor Hossain Miah ${ }^{1}$, Mozammel Hoque ${ }^{1}$, Md. Sazzad \\ Hossain $^{1}$ and ${ }^{\otimes}$ Ahmed Khairul Hasan ${ }^{2}$ \\ ${ }^{1}$ Department of Agronomy and Haor Agriculture, Sylhet Agricultural University, Sylhet-3100, Bangladesh \\ ${ }^{2}$ Department of Agronomy, Bangladesh Agricultural University, Mymensingh-2202, Bangladesh
}

ARTICLE INFO ${ }_{\text {OPENOACCES }}$
Article history:
Received : 31 May 2018
Accepted : 19 November 2018
Published: 31 December 2018

Keywords:

BRRI dhan50; Soil acidity; Lime;

FYM; Fertilizer

Correspondence:

Ahmed Khairul Hasan

凶: akhasan@bau.edu.bd

\begin{abstract}
The effect of lime and fertilizer application, as the management of soil acidity, on the growth and yield of rice cv. BRRI dhan50 was investigated during Aman rice season at the Agronomy Field Laboratory of Sylhet Agricultural University, Bangladesh. The experiment was consisted of two factors namely lime and fertilizer. There were four levels of lime $\left(0,0.50,1.00\right.$, and $1.50 \mathrm{t} \mathrm{ha}^{-1}$ of $\left.\mathrm{CaCO}_{3} \cdot \mathrm{MgCO}_{3}\right)$ and three levels of fertilizers (control, FYM @ $10 \mathrm{t} \mathrm{ha}^{-1}$, and chemical fertilizer @ 100-30-42-4-3-0.4 kg ha ${ }^{-1}$ of N-P-K$\mathrm{Ca}-\mathrm{S}-\mathrm{Zn}$ ). The experiment was laid out in a randomized complete block design with three replications where the unit plot size was $4.0 \mathrm{~m} \times 2.5 \mathrm{~m}$. Growth parameters, yield components and yield of BRRIdhan 50 rice increased with increasing lime rate in association of fertilizer in acidic soil. The highest grain yield $\left(2.90 \mathrm{t} \mathrm{ha}^{-1}\right)$ was recorded from the application of $1.50 \mathrm{t} \mathrm{ha}^{-1}$ lime and the lowest $\left(2.06 \mathrm{t} \mathrm{ha}^{-1}\right)$ was from control $\left(0 \mathrm{t} \mathrm{ha}^{-1}\right)$, irrespective of fertilizer. On the other hand, the best effect of fertilizers on grain yield $\left(3.08 \mathrm{tha}^{-1}\right)$ was found with the application of FYM @ $10 \mathrm{tha}^{-1}$ and the lowest yield $\left(1.59 \mathrm{tha}^{-1}\right)$ was in control. The treatment combination of lime $1.50 \mathrm{t} \mathrm{ha}^{-1}$ and FYM (@ $10 \mathrm{t} \mathrm{ha}^{-1}$ produced the highest grain yield $\left(3.60 \mathrm{t} \mathrm{ha}^{-1}\right)$, which was followed by treatment combination of lime $1.50 \mathrm{t} \mathrm{ha}^{-1}$ and chemical fertilizer @ 100-30-42-4-3-0.4 kg ha ${ }^{-1}$ of N-P-K-Ca-S-Zn (3.28 t ha $\left.{ }^{-1}\right)$. Additionally, application of lime and FYM improved the soil fertility and properties of acidic soil for crop production by increasing the $\mathrm{pH}$, organic matter and availability of some essential nutrients. From the study, it was indicated that both FYM and lime could affect to enhance the grain yield of rice in acidic soil.
\end{abstract}

\section{Introduction}

Rice (Oryza sativa $\mathrm{L}$.) is the staple food for nearly half of the population and second most widely cultivated crop plant in the world (FAO, 2008; Huang et al., 2010). Rice is the most extensively cultivated crop in Bangladesh, but yield is far below $\left(4.5 \mathrm{t} \mathrm{ha}^{-1}\right)$ than that of many other countries like China $6.8 \mathrm{t} \mathrm{ha}^{-1}$, in Japan $6.7 \mathrm{t} \mathrm{ha}^{-1}$, in Korea $7.2 \mathrm{t} \mathrm{ha}^{-1}$ and USA $8.4 \mathrm{t} \mathrm{ha}^{-1}(\mathrm{FAO}$, 2017). Aromatic rice varieties constitute a small but elite group of rice and have gained greater importance with the worldwide increase in the demand of rice. Recently some modern aromatic rice varieties have been developed like, BRRI dhan34, BRRI dhan50 (Banglamoti), Binadhan-9 and Binadhan-13 etc. Cultivation of aromatic rice is becoming popular for its high price and export potential. Not only is aroma one of the most important characteristics for determining excellent quality rice but aromatic varieties have comparable or superior nutritional values and better amino acid profiles, for example, Basmati rice having a higher lysine, phenylalanine, leucine and methionine content than non-aromatic varieties (Sekhar and Reddy, 1982). Bangladesh Rice Research Institute has developed an aromatic fine rice variety BRRI dhan50 (Banglamoti) like the Basmati rice of Pakistan and India, but its yield was expected to be double. Thus, Banglamoti rice was trialed in different regions of Bangladesh and could be cultivated in both Aman and Boro seasons. Hoque et al. (2013) reported that BRRI

\section{Cite this article}

Ferdous S.A., Miah M.N.H., Hoque M., Hossain M.S. and Hasan A.K. 2018. Enhancing rice yield in acidic soil through liming and fertilizer management. Journal of Bangladesh Agricultural University, 16(3): 357-365. dhan50 is a potential variety of aromatic fine rice for Sylhet region of Bangladesh.

Most of the agricultural soils of Sylhet region are acidic in nature with $\mathrm{pH}$ value of 4.9-6.1 (Hossain and Sattar, 2002). Liming of acid soils changes the $\mathrm{pH}$, rectifies adverse effects and also improves the soil fertility (Reddy and Subramanian, 2016). A judicious application of lime and fertilizer may help overcome this problem of soil acidity although rice can be grown from $\mathrm{pH}$ level 5.5 to higher level. But soil with extreme low $\mathrm{pH}$ may need liming for having a good yield. Sub-optimal rate of lime cannot raise soil $\mathrm{pH}$ to a target one. On the other hand, too much addition of lime can decrease the availability of micronutrients, especially $\mathrm{Fe}, \mathrm{Mn}, \mathrm{Zn}$ and $\mathrm{Cu}$ sufficiently to cause deficiencies of those plant nutrients (Haynes, 1982). Also, over dose of lime application makes insoluble form of phosphate combined with $\mathrm{Ca}$ and $\mathrm{Mg}$ (Westermann, 1992; Murphy and Sims, 2012). So, determination of an accurate lime requirement for an acid soil is important to bring soil $\mathrm{pH}$ in suitable range for facilitating nutrient availability to plants and thereby encourage proper growth and yield of crops.

In addition to soil acidity, the widespread problem of Bangladesh soil is the declination of soil fertility gradually. Low organic matter content of the soil, imbalanced use of chemical fertilizers, less use of 
organic manures and inadequate attention given for its improvement and maintenance have made the situation difficult (Karim et al., 1994). Before 1980's, deficiency of NPK was a major problem of Bangladesh soil but thereafter along with NPK deficiencies of S and $\mathrm{Zn}$ are frequently reported (Islam and Hossain, 1993; Haque and Jahiniddin, 1994). Presently, there has been a great increase in fertilizer use, yet different nutrients used in the country are not balanced. In Bangladesh most of the cultivated soils have less than $1.5 \%$ organic matter (Rahman et al., 2014), whereas good agricultural soil should contain of least $2 \%$ organic matter. Moreover, this important component of soil is declining with time due to intensive cropping and use of higher doses of fertilizers with little or no addition of' organic matter. In general, organic manures improve soil physical, chemical and biological properties in addition to supplying substantial quantities of plant nutrients and chemical NPK fertilizers would be quite promising in providing greater stability in production (Karažija et al., 2015).

The problem of nutrient deficiencies as well as nutrient mining caused by intensive cropping with HYV of rice and nutrient imbalance can be minimized by judicious application of nutrients through organic manures. Losses of soil organic matter can only be replenished in the short term by application of organic matter such as manures like FYM (Farmyard manure), compost, and decomposed cow dung. FYM is the well decomposed mixture of cow dung, urine and straw materials used as bedding and feed residual of farm animal; which is rich in organic matter and plant nutrient element (Gowarikeret al., 2009). Application of organic manure alone or in combination with recommended fertilizer dose can play important role in rice cultivation. Hoque et $a l$. (2016) reported that, application of well decomposed cow dung in BRRI dhan50 produced the maximum grain yield in comparison to chemical fertilizers.

Fertilizers both chemical and organic may eventually make the soil more acidic. Hydrogen is added in the form of ammonia-based fertilizers $\left(\mathrm{NH}_{4}{ }^{+}\right)$, Urea-based fertilizers $\left[\mathrm{CO}\left(\mathrm{NH}_{2}\right)_{2}\right]$ and as proteins (amino acids) in organic fertilizers. Transformation of these sources of $\mathrm{N}$ into nitrate $\left(\mathrm{NO}_{3}{ }^{-}\right)$releases $\mathrm{H}^{+}$to create soil acidity (Caires et al., 2005). Therefore, fertilization with ammonium or even adding large quantities of organic matter to a soil will ultimately increase the soil acidity and lower the $\mathrm{pH}$. Therefore, the present research work was undertaken to observe the effects of different level of lime application to acid soils along with 3 levels of fertilizer to ameliorate soil acidity and its impact on productivity of rice variety BRRI dhan50 (Banglamoti).

\section{Materials and Methods}

\section{Experimental site and soil properties}

The experiment was conducted at the experimental field of Sylhet Agricultural University (SAU), Sylhet, during the period of July to December 2012. The experimental area belongs to the highly acidic and silty clay loam soil under Agro-ecological Zone Northern and Eastern Piedmont Plain (AEZ 22). Before starting the experiment, initial composite soil samples $(0-15 \mathrm{~cm}$ depth) were collected from the experimental plots and analyzed using available laboratory techniques. The soil was silty loam with low organic matter $(1.38 \%)$ and acidic in nature $(\mathrm{pH} 5.2)$. The $\mathrm{N}(0.11 \%)$ and $\mathrm{S}(22$ $\mathrm{ppm})$ content werelow and $\mathrm{P}(47.0 \mathrm{ppm})$ content was very low. The $\mathrm{K}(0.18 \mathrm{meq} / 100 \mathrm{~g}), \mathrm{Zn}(0.98 \mathrm{ppm})$ and $\mathrm{B}$ $(0.40 \mathrm{ppm})$ content weremedium (Table 1$)$.

\section{Plant materials and Treatments}

The rice variety used in the experiment is BRRI dhan50 (Banglamoti) which was collected from Bangladesh Rice Research Institute (BRRI), Joydebpur, Gazipur, Bangladesh. BRRI dhan50 is long-grain aromatic fine rice, almost similar to $\mathrm{cv}$. Bashmati. Lime dolomite dust $\left[\mathrm{CaCO}_{3} \cdot \mathrm{MgCO}_{3}\right]$ of agricultural field grade and chemical fertilizers were collected from local market of Sylhet, Bangladesh. FYM was collected from government dairy farm, Sylhet, Bangladesh. The experiment comprised of two factors: (a). lime (four levels): i) Control $\left(\mathrm{t} \mathrm{ha}^{-1}\right)$, ii) $0.5\left(\mathrm{t} \mathrm{ha}^{-1}\right)$, iii) $1.0\left(\mathrm{t} \mathrm{ha}^{-1}\right)$ and iv) $1.5\left(\mathrm{t} \mathrm{ha}^{-1}\right)$. (b) fertilizer (three levels): i) control ii) FYM @ $10 \mathrm{t} \mathrm{ha}^{-1}$ and iii) chemical fertilizer @ 10030-42-3-0.4 $\mathrm{kg} \mathrm{ha}^{-1}$ of N-P-K-S-Zn (farmers practice).

\section{Preparation of experimental plots and growing crop}

The selected experimental field was first opened by a power tiller in dry condition and then ploughed again and cross ploughed under wet condition followed by laddering to get a good puddle. Weeds and stubbles were removed from the field the land was mudded and leveled well before laying out. The layout of the experiment was done in accordance with the design adopted with a unit plot size of $10 \mathrm{~m}^{2}(4.0 \mathrm{~m} \times 2.5 \mathrm{~m})$ and the total number of plots were 36. Each treatment was replicated thrice. Lime was applied as dolomite dust $\left[\mathrm{CaCo}_{3} \cdot \mathrm{MgCO}_{3}\right]$ before 10 days of transplanting of rice as per treatments. At the final land preparation, FYM, triple super phosphate (TSP), muriate of potash (MoP), gypsum and zinc fertilizers were applied according to treatments. Lime and fertilizers were thoroughly mixed with soil by spading. Urea was top dressed in three equal splits at 15, 35 and 50 days after transplanting. Seedlings were grown in nursery bed with proper care and management, 32 days-old seedlings were transplanted at $20 \mathrm{~cm} \times 15$ $\mathrm{cm}$ spacing as single seedling per hill. Irrigation, weeding and plant protection measures were taken as per necessity.

\section{Data collection and analysis}

Five hills from each plot were randomly selected for collecting data on growth and yield parameters. The crops were harvested at full maturity. Five randomly selected plants were uprooted for data recording on plant and yield parameters like plant height, total tillers hill ${ }^{-1}$, effective tillers hill ${ }^{-1}$, panicle length, spikelets panicle ${ }^{-1}$, grains panicle- ${ }^{1}$, sterile grains panicle ${ }^{-1}$, disease spotted seed, 1000-spikelets weight, grain yield, straw yield and 
harvest index (ratio of grain yield and biological yield). Grain and straw yields were recorded after sun drying. Moisture in grain was determined using moisture meter (GMK-303RS) and adjusted at $14 \%$ by sun drying. Data were statistically analyzed using the Analysis of variance (ANOVA) technique with the help of computer package program (MSTAT). The mean differences were adjudged by Duncan's Multiple Range Test (DMRT) (Gomez and Gomez, 1984).

\section{Results and Discussion}

Effect of lime and fertilizer on plant characters and yield of BRRI Dhan50

Results and discussion on effect of individual effect of lime and fertilizers and their interactions were discussed below. All the plant and yield characters studied in this experiment showed significant variation due to liming, fertlizer application or due to their interaction (Table 2, 3 and 4).

\section{Plant height}

Application of lime @ $0.50 \mathrm{t} \mathrm{ha}^{-1}$ produced the maximum plant height $(75.90 \mathrm{~cm})$ while the control treatment had the shortest plants $(71.68 \mathrm{~cm})$. The positive effects of liming on crops have been reported to increase plant height in acidic soil (Alfaons et al., 2008). The effect of fertilizer from various sources had significant influence on plant height of BRRI dhan50 rice (Table 3). The highest plant height $(78.71 \mathrm{~cm})$ was observed in case of chemical fertilizer dose 100-30-424-3-0.4 kg ha ${ }^{-1}$ of N-P-K-Ca-S-Zn $\left(\mathrm{F}_{3}\right)$ which was followed by organic fertilizer $\left(\mathrm{F}_{3}\right)$ i.e., FYM @ $10 \mathrm{tha}^{-1}$ $(75.9 \mathrm{~cm})$ and the lowest $(69.1 \mathrm{~cm})$ was observed in $F_{1}$ (control). One of the major reasons of this effect might be due to high dose of fertilizer specially nitrogen which increased the plant height. Plant height is mostly governed by the genetic makeup of the cultivar, but the environmental factors also influence it. Mohammad et al. (2002) also reported that application $\mathrm{N}$ increase the plant height of rice. Muhammad et al. (2005) conducted an experiment with fine grain rice cv. Basmati 2000 involving seven nitrogen rates, i.e. $0,25,50,75,100$, 125 and $150 \mathrm{~kg} \mathrm{ha}^{-1}$ and found that $150 \mathrm{~kg} \mathrm{~N}^{-1}$ produced the tallest plant that was statistically similar to $125 \mathrm{~kg} \mathrm{~N} \mathrm{ha}^{-1}$. Similar result was also reported by Chopra and Chopra (2004) in rice.

The data presented in Table 4 indicated that with the increased fertilizer level and lime, plant height increased progressively. The interaction of $\mathrm{L}_{4} \mathrm{~F}_{1}$ produced the least plant height $(66.4 \mathrm{~cm})$ and the maximum plant height was observed in $\mathrm{L}_{4} \mathrm{~F}_{3}(81.6 \mathrm{~cm})$. It could be observed from the data presented in Table 4 that there was an increasing trend of plant height with increasing rate of lime and fertilizer treatment levels $F_{1}$ to $F_{3}$.

\section{Number of tillershill ${ }^{-1}$}

The maximum number of tillers (21.33) and number of effective tillers (16.15) hill ${ }^{-1}$ was recorded at $\mathrm{L}_{4}$ (lime @ $\left.1.50 \mathrm{t} \mathrm{ha}^{-1}\right)$, and minimum total (17.07) and effective tillers (13.97) was found in $\mathrm{L}_{1}$ (Control). Patiram and
Prasad (1990) conducted an experiment on an acid soil to evaluate the effect of dolomite limestone on rice yield and they observed that dolomite limestone increased soil $\mathrm{pH}$ and number of tiller significantly. These results supported the previous findings that lime is effective in alleviating soil acidity (Venkatesh et al., 2002; Chang and Sung, 2004; Cifu et al., 2004; Caires et al., 2008).

Number of panicles was the result of the number of tillers produced and the proportion of effective tillers which survived to produce panicle. In this study, number of total tillers hill ${ }^{-1}$ of BRRI dhan50 was also influenced by fertilizer treatment (Table 3). The highest number of total tillers hill ${ }^{-1}(23.4 \mathrm{~cm})$ was recorded in $\left(\mathrm{F}_{3}\right)$ and the lowest number of tillers hill ${ }^{-1}(14.4)$ was found in $F_{1}$ (control). Wagh and Thorat (1988) reported that increased rate of NPK and other fertilizer significantly increased the total tillers hill ${ }^{-1}$ in rice. Maske et al. (1997) reported that number of tillers hill ${ }^{-1}$ increased significantly with increased $\mathrm{N}$ level in rice. The reclamation of soil acidity through lime and fertilizer management in Banglamoti rice had significant effect on the number of effective tillers hill ${ }^{-1}$ irrespective of lime rate (Table 2 and 4). The results indicated that the maximum number of effective tillers $\operatorname{hill}^{-1}(17.8)$ was produced by the treatment of organic fertilizer FYM $\left(\mathrm{F}_{2}\right)$ and lowest number of effective tiller $\operatorname{hill}^{-1}(11.8)$ was recorded from $\mathrm{L}_{1}$ (Control) presented in Table 3. Herve et al. (2017) reported that effective tillers increased with increasing application of $\mathrm{N}$ fertilizer levels in rice.

The number of total tiller production in different in treatments showed that it fluctuated from one treatment combination to another and also from treatment to treatment. The data presented in Table 4 indicated that with the increased of lime, fertilizer treatment from $F_{1}$ to $\mathrm{F}_{3}$, the number of tillers increased significantly. The treatment combination $\mathrm{L}_{3} \mathrm{~F}_{3}$ produced the maximum number of total tillershill ${ }^{-1}(27.1)$ and it was followed by $\mathrm{L}_{4} \mathrm{~F}_{3}$ and the minimum number of tiller production was observed in $\mathrm{L}_{1} \mathrm{~F}_{1}$ (Table 4). It was observed that interaction effect of lime and fertilizer on number of effective tiller hill ${ }^{-1}$ was significant at $1 \%$ level of probability (Table 4). The highest number of effective tillers $\operatorname{hill}^{-1}(21.5)$ was observed from the treatment combination of $\mathrm{L}_{4} \mathrm{~F}_{2}$ in BRRI dhan50 and the lowest number of effective tiller hill ${ }^{-1}(9.6)$ was recorded in the combination $\mathrm{L}_{1} \mathrm{~F}_{1}$ (Table 4). It could be seen from the data presented in Table 4 that with increased rate of lime and fertilizer treatments of $F_{1}$ to $F_{3}$, the number of effective tillers hill $^{-1}$ showed an increased trend except $\mathrm{L}_{4} \mathrm{~F}_{3}$.

\section{Panicle length}

The results revealed that different liming rates had significant effect on panicle length. The longest panicle $(21.49 \mathrm{~cm})$ was recorded with lime rate $1.50 \mathrm{t} \mathrm{ha}^{-1}\left(\mathrm{~L}_{4}\right)$ and shortest panicle $(19.48 \mathrm{~cm})$ was recorded in control ( $0 \mathrm{t} \mathrm{ha}^{-1}$ lime). Panicle length without lime was the least which indicated that high acidity restricted its length. Similar results of the lowest panicle were reported by with Banerjee and Das (2001). 
The differences among the fertilizer doses irrespective of lime rate of panicle length were found to be statistically significant (Table 3). The longest panicle $(21.7 \mathrm{~cm})$ was found in organic manure cow dung $\left(\mathrm{F}_{2}\right)$. The smallest panicle $(18.6 \mathrm{~cm})$ was observed in control treatment $\left(\mathrm{F}_{1}\right.$, no fertilizer). Azad et al. (1995) noted significant increased panicle length with the increased levels of fertilizer nitrogen. Hasanuzzaman et al. (2010) observed that application of cow dung and urea-N alone or in combination exerted positive effect on panicle length of BRRI Dhan50. A significant increase in panicle length was due to application of organic manures and fertilizer nitrogen, sulphur, zinc and boron. However, the longest panicle $(25.0 \mathrm{~cm})$ was recorded in the interaction $\mathrm{L}_{4} \mathrm{~F}_{2}$ and the minimum panicle length was recorded $(17.7 \mathrm{~cm})$ in the combination $\mathrm{L}_{1} \mathrm{~F}_{1}$.

\section{Number of spikeletspanicle ${ }^{-1}$}

The mean data of number of spikelets panicle ${ }^{1}$ irrespective of fertilizer treatment showed a significantly variation due to application of lime in the acid soil. The number of spikelets panicle ${ }^{-1}$ ranged from 113.5 to 122.0 . The highest was recorded in $\mathrm{L}_{4}$ where total number of spikeletspanicle $e^{-1}$ was 122.0 . It is evident from the Table 1 that maximum number of spikelets panicle ${ }^{-1}$ was recorded from those plots where lime applied was applied $1.50 \mathrm{t} \mathrm{ha}^{-1}$. Liming of acid soil has been suggested as the most efficient practice to attain and maintain a suitable $\mathrm{pH}$ for the growth of panicle of crops (Slattery and Conventry, 1993; Moody et al., 1995). Improvement of soil productivity by liming can increase crop yields, as observed in wheat (Coventry et al., 1997; Scott et al., 2001) and rice crops.

A significantly variation in total spikelets panicle ${ }^{-1}$ was observed due to fertilizer treatment of manures, fertilizers and control (Table 3). The number spikelets panicle $^{-1}$ ranged from 101.9 to 125.9 . The highest and lowest numbers of spikelets panicle ${ }^{-1}$ were recorded from the treatments $F_{2}$ and $F_{1}$, respectively. Application of organic manure cow dung $10 \mathrm{t} \mathrm{ha}^{-1}$ and chemical fertilizer at recommended dose $\left(\mathrm{F}_{2}\right)$ produced spikelets panicle $^{-1} 125.9$ and 122.4, respectively which was statistically similar. Table 2 also showed that BRRI Dhan50 responded better to the nutrients supplied from the organic manure as compared to those from the chemical fertilizer. Mondal et al. (1990) reported that spikelets panicle ${ }^{-1}$ with increasing NPK rates and FYM application. Hasanuzzaman et al. (2010) observed significantly increased number of grainspanicle ${ }^{-1}$ from manure treated plots. They reported that increasing rates fertilizer application increased grainspanicle ${ }^{1}$ significantly over control in rice. Similar result was reported in fine grain rice (BINA, 2009).

The interaction between lime and fertilizer treatment had significant effect on the number of spikelets panicle ${ }^{1}$ (Table 4). The highest number of spikelets panicle ${ }^{1}(136.1)$ observed from the combination $\mathrm{L}_{4} \mathrm{~F}_{2}$ and the lowest number of spikelets panicle ${ }^{-1}(99.6)$ was observed in the combination of $\mathrm{L}_{2} \mathrm{~F}_{1}$ which was statistically similar in treatment combination $\mathrm{L}_{1} \mathrm{~F}_{1}$ (Table 4). Positive responses of lime on different crop yield in acid soil were reported Caires et al. 2005; Reddy and Subramanian, 2016; Westermann, 1992; Venkatesh et al. 2002). They reported that, management of soil performed better in producing more grains either alone or in combination with lime and fertilizer in acid soil and increase number of grainspanicle ${ }^{-1}$.

\section{Number of unfilled spikelets panicle ${ }^{-1}$}

Data presented in Table 2 showed that lime rate @0 t $\mathrm{ha}^{-1}\left(\mathrm{~L}_{1}\right)$ i.e. control produced the maximum number of unfilled spikelets $(27.01 \%)$ followed by $\mathrm{L}_{2}(22.9 \%), \mathrm{L}_{3}$ $(20.9 \%)$ whereas the lowest number of unfilled spikelets (21.0\%) was recorded in $\mathrm{L}_{4}\left(1.50 \mathrm{tha}^{-1}\right.$ of lime). These results indicated that lime application had positive effect on filled grain which ultimately produced higher yield.

Chemical fertilizer $\left(\mathrm{F}_{3}\right)$ irrespective of lime rate produced the maximum number of unfilled spikelets (24.9\%) although it was statistically similar to $F_{1}$. Similarly, disease spotted seed was also the highest in $\mathrm{F}_{3}$ (18.23) and the lowest in $F_{2}(12.54)$.

Interaction effect between lime and fertilizer management in BRRI dhan50 did not follow any trend in respected of unfilled spikelets (Table 4). However, the highest unfilled spikelets $(31.2 \%)$ was recorded from the combination of $\mathrm{L}_{1} \mathrm{~F}_{3}$ and the lowest $(17.0 \%)$ was observed from combination of $\mathrm{L}_{4} \mathrm{~F}_{2}$ (Table 4).

\section{Number of diseased spotted spikelets panicle ${ }^{-1}$}

BRRI dhan50 was susceptible to insects and diseases and soil management influence the susceptibility. Application of lime at $1.50 \mathrm{t} \mathrm{ha}^{-1}$ produced lowest percentage of diseases spotted spikelets (13.39\%). Chemical fertilizer $\left(\mathrm{F}_{3}\right)$ irrespective of lime rate caused disease spotted seed which was also the highest in $\mathrm{F}_{3}$ (18.23) and the lowest in $F_{2}$ (12.54). Interaction effect between lime and fertilizer management in BRRI dhan50 revealed the lowest percentage of diseases spotted seed in $\mathrm{L}_{4} \mathrm{~F}_{2}(10.50)$ and the highest in $\mathrm{L}_{1} \mathrm{~F}_{3}$ (23.80 followed by $\mathrm{L}_{1} \mathrm{~F}_{1}(20.13)$.

\section{Thousand-grain weight}

The 1000-grain weight was affected by different levels of lime (Table 2). The highest 1000-grain weight (18.53 g) was produced by treatment $\mathrm{L}_{4}$ (lime rate $1.50 \mathrm{t} \mathrm{ha}^{-1}$ ). On the other hand, treatment $\mathrm{L}_{2}$ (lime rate $0.50 \mathrm{t} \mathrm{ha}^{-1}$ ) produced the lowest 1000 -grain weight (17.78 g) which was similar to $\mathrm{L}_{1}$ and $\mathrm{L}_{3}$. The 1000 -grain weight was significantly affected by different levels of lime. Application of lime increased 1000-grain weight over less liming. The reduced soil acidity and higher nutrient availability because of liming enhanced crop growth and increase yield contributing character 1000-grain weight which resulted in higher yields (Scott et al., 1999; The et al., 2006). 
Table 1. Characteristics of the soil before treatment application and after harvesting of the crops

\begin{tabular}{|c|c|c|c|c|c|c|c|c|}
\hline Chemical analysis & Treatments & $\mathrm{pH}$ & $\mathrm{OM}(\%)$ & $\mathrm{N}(\%)$ & $\mathrm{K}(\mathrm{meq} / 100 \mathrm{~g})$ & $\mathrm{P}(\mathrm{ppm})$ & $\mathrm{S}(\mathrm{ppm})$ & $\mathrm{Zn}(\mathrm{ppm})$ \\
\hline Initial soil & & 5.2 & 1.38 & 0.11 & 0.18 & 47 & 22 & 0.98 \\
\hline \multirow{6}{*}{ Post-harvest soil } & Control & 5.2 & 1.38 & 0.11 & 0.18 & 42 & 23 & 0.98 \\
\hline & FYM & 5.2 & 1.42 & 0.13 & 0.19 & 45 & 29 & 3.02 \\
\hline & Fertilizer & 5.2 & 1.39 & 0.14 & 0.18 & 48 & 39 & 3.11 \\
\hline & Lime@50kg ha-1 & 5.4 & 1.38 & 0.12 & 0.17 & 43 & 29 & 3.0 \\
\hline & Lime@100kg ha-1 & 5.7 & 1.39 & 0.13 & 0.17 & 46 & 33 & 3.0 \\
\hline & Lime@150kg ha-1 & 6.0 & 1.39 & 0.14 & 0.16 & 46 & 37 & 3.02 \\
\hline
\end{tabular}

Table 2. Effect of lime on plant characters and yield of rice cv. BRRI dhan50

\begin{tabular}{lccccccccccc}
\hline Lime & $\begin{array}{c}\text { Plant } \\
\text { height } \\
(\mathrm{cm})\end{array}$ & $\begin{array}{c}\text { Tillers } \\
\text { hill }^{-1} \\
(\text { No. })\end{array}$ & $\begin{array}{c}\text { Effective } \\
\text { tillers hill }^{-1} \\
(\text { No. })\end{array}$ & $\begin{array}{c}\text { Panicle } \\
\text { length } \\
(\mathrm{cm})\end{array}$ & $\begin{array}{c}\text { Spikelets } \\
\text { panicle }^{-1} \\
(\text { No. })\end{array}$ & $\begin{array}{c}\text { Unfilled } \\
\text { spikelets } \\
(\%)\end{array}$ & $\begin{array}{c}\text { Disease } \\
\text { spotted } \\
\text { spikelets }(\%)\end{array}$ & $\begin{array}{c}1000- \\
\text { grain } \\
\text { weight }(\mathrm{g})\end{array}$ & $\begin{array}{c}\text { Grain } \\
\text { yield } \\
\left(\mathrm{t} \mathrm{ha}^{-1}\right)\end{array}$ & $\begin{array}{c}\text { Straw } \\
\left.\text { yield } \mathrm{t}^{-1}\right)\end{array}$ & $\begin{array}{c}\text { Harvest } \\
\text { index } \\
(\%)\end{array}$ \\
\hline L1 & $71.68 \mathrm{~b}$ & $16.15 \mathrm{~b}$ & $13.97 \mathrm{~b}$ & $19.48 \mathrm{~b}$ & $113.5 \mathrm{~b}$ & $27.01 \mathrm{a}$ & $18.17 \mathrm{a}$ & $17.91 \mathrm{~b}$ & $2.06 \mathrm{~d}$ & $2.58 \mathrm{c}$ & $43.82 \mathrm{a}$ \\
L2 & $75.90 \mathrm{a}$ & $19.30 \mathrm{a}$ & $15.96 \mathrm{a}$ & $20.13 \mathrm{ab}$ & $112.5 \mathrm{~b}$ & $22.86 \mathrm{~b}$ & $16.91 \mathrm{a}$ & $17.87 \mathrm{~b}$ & $2.41 \mathrm{c}$ & $3.04 \mathrm{~b}$ & $43.97 \mathrm{a}$ \\
L3 & $75.21 \mathrm{a}$ & $21.11 \mathrm{a}$ & $15.49 \mathrm{ab}$ & $21.06 \mathrm{ab}$ & $119.0 \mathrm{a}$ & $20.88 \mathrm{~b}$ & $13.50 \mathrm{~b}$ & $18.03 \mathrm{~b}$ & $2.71 \mathrm{~b}$ & $3.46 \mathrm{a}$ & $43.63 \mathrm{a}$ \\
L4 & $75.50 \mathrm{a}$ & $21.33 \mathrm{a}$ & $17.07 \mathrm{a}$ & $21.49 \mathrm{a}$ & $122.0 \mathrm{a}$ & $20.98 \mathrm{~b}$ & $13.39 \mathrm{~b}$ & $18.53 \mathrm{a}$ & $2.90 \mathrm{a}$ & $3.54 \mathrm{a}$ & $43.61 \mathrm{a}$ \\
CV $(\%)$ & 3.89 & 6.53 & 7.50 & 5.46 & 2.65 & 6.84 & 9.90 & 1.37 & 3.72 & 3.89 & 3.79 \\
LSD & 4.98 & 2.16 & 1.98 & 1.89 & 5.24 & 2.65 & 2.59 & 0.42 & 0.16 & 0.2074 & 2.81 \\
Sig. level & $*$ & $* *$ & $* *$ & $* *$ & $* *$ & $* *$ & $* *$ & $* *$ & $* *$ & $*$ & $*$ \\
\hline
\end{tabular}

In a column, means followed by common letters are not significantly different from each other at $5 \%$ or $1 \%$ level of probability according to DMRT. $*=$ Significant at $5 \%$ level, $* *=$ Significant at $1 \%$ level. $\mathrm{L} 1=$ lime $0 \mathrm{t} \mathrm{ha}^{-1}, \mathrm{~L} 2=$ lime $0.5 \mathrm{t} \mathrm{ha}{ }^{-1}, \mathrm{~L} 3=$ lime $1.0 \mathrm{t} \mathrm{ha}^{-1} \mathrm{~L} 4=$ lime $1.5 \mathrm{t} \mathrm{ha}^{-1}$.

Table 3. Effect of fertilizer on the plant characters and yield of rice cv. BRRI dhan50

\begin{tabular}{lccccccccccc}
\hline Fertilizers & $\begin{array}{c}\text { Plant } \\
\text { height } \\
(\mathrm{cm})\end{array}$ & $\begin{array}{c}\text { Tillers } \\
\text { hill }^{-1} \\
(\text { No. })\end{array}$ & $\begin{array}{c}\text { Effective } \\
\text { tillers hill }^{-1} \\
(\text { No. })\end{array}$ & $\begin{array}{c}\text { Panicle } \\
\text { length } \\
(\mathrm{cm})\end{array}$ & $\begin{array}{c}\text { Spikelets } \\
\text { panicle }^{-1} \\
(\text { No. })\end{array}$ & $\begin{array}{c}\text { Unfilled } \\
\text { spikelets } \\
(\%)\end{array}$ & $\begin{array}{c}\text { Disease } \\
\text { spotted } \\
\text { spikelets }(\%)\end{array}$ & $\begin{array}{c}\text { 1000-grain } \\
\text { weight }(\mathrm{g})\end{array}$ & $\begin{array}{c}\text { Grain } \\
\text { yield } \\
\left(\mathrm{t} \mathrm{ha} \mathrm{h}^{-1}\right)\end{array}$ & $\begin{array}{c}\text { Straw } \\
\text { yield } \\
\left(\mathrm{tha}^{-1}\right)\end{array}$ & $\begin{array}{c}\text { Harvest } \\
\text { index } \\
(\%)\end{array}$ \\
\hline F1 & $69.09 \mathrm{~b}$ & $14.37 \mathrm{c}$ & $11.83 \mathrm{~b}$ & $18.59 \mathrm{~b}$ & $101.9 \mathrm{~b}$ & $23.15 \mathrm{ab}$ & $16.70 \mathrm{a}$ & $17.01 \mathrm{c}$ & $1.585 \mathrm{c}$ & $2.40 \mathrm{~b}$ & $40.01 \mathrm{~b}$ \\
F2 & $75.92 \mathrm{a}$ & $20.70 \mathrm{~b}$ & $17.84 \mathrm{a}$ & $21.69 \mathrm{a}$ & $125.9 \mathrm{a}$ & $20.73 \mathrm{~b}$ & $12.54 \mathrm{~b}$ & $18.92 \mathrm{a}$ & $3.084 \mathrm{a}$ & $3.51 \mathrm{a}$ & $46.45 \mathrm{a}$ \\
F3 & $78.71 \mathrm{a}$ & $23.35 \mathrm{a}$ & $17.18 \mathrm{a}$ & $21.33 \mathrm{a}$ & $122.4 \mathrm{a}$ & $24.91 \mathrm{a}$ & $18.23 \mathrm{a}$ & $18.33 \mathrm{~b}$ & $2.892 \mathrm{~b}$ & $3.56 \mathrm{a}$ & $44.81 \mathrm{a}$ \\
CV $(\%)$ & 3.89 & 6.53 & 7.50 & 5.46 & 2.65 & 6.84 & 9.90 & 1.37 & 3.72 & 3.89 & 3.79 \\
LSD & 4.91 & 2.16 & 1.99 & 1.89 & 5.24 & 2.65 & 2.59 & 0.42 & 0.16 & 0.20 & 2.81 \\
Sig. level. & $* *$ & $* *$ & $* *$ & $* *$ & $* *$ & $* *$ & & $* *$ & $* *$ & $* *$ & $* *$ \\
\hline
\end{tabular}

In a column, means followed by common letters are not significantly different from each other at $5 \%$ or $1 \%$ level of probability according to DMRT. $*$ = Significant at $\%$ level, $* *=$ significant at $1 \%$ level. $\mathrm{F} 1=$ fertilizer $0 \mathrm{t} \mathrm{ha}^{-1}, \mathrm{~F} 2=$ fertilizer $(\mathrm{FYM}) 10 \mathrm{t}$ ha ${ }^{1}, \mathrm{~F} 3=$ fertilizer (chemical) $100-30-42-4-3-0.4 \mathrm{~kg} \mathrm{ha}^{-1}$ of N-P-K-Ca-S-Zn.

Table 4. Interaction effect of lime and fertilizer on the plant characters and yield of rice cv. BRRI dhan50

\begin{tabular}{|c|c|c|c|c|c|c|c|c|c|c|c|}
\hline $\begin{array}{c}\text { Interactions } \\
\text { (lime } \times \\
\text { fertilizer) }\end{array}$ & $\begin{array}{l}\text { Plant } \\
\text { height } \\
(\mathrm{cm})\end{array}$ & $\begin{array}{l}\text { Tillers } \\
\text { hill }^{-1} \\
\text { (No.) }\end{array}$ & $\begin{array}{l}\text { Effective } \\
\text { tillers hill }^{-1} \\
\text { (No.) }\end{array}$ & $\begin{array}{c}\text { Panicle } \\
\text { length } \\
(\mathrm{cm})\end{array}$ & $\begin{array}{c}\text { Spikelets } \\
\text { panicle }^{-1} \\
\text { (No.) }\end{array}$ & $\begin{array}{c}\text { Unfilled } \\
\text { spikelets } \\
(\%)\end{array}$ & $\begin{array}{c}\text { Disease } \\
\text { spotted } \\
\text { spikelets } \\
(\%)\end{array}$ & $\begin{array}{c}1000- \\
\text { grain } \\
\text { weight } \\
(\mathrm{g})\end{array}$ & $\begin{array}{l}\text { Grain } \\
\text { yield } \\
\left(\mathrm{t} \mathrm{ha}^{-1}\right)\end{array}$ & $\begin{array}{l}\text { Straw } \\
\text { yield } \\
\left(\mathrm{t} \mathrm{ha}^{-1}\right)\end{array}$ & $\begin{array}{c}\text { Harvest } \\
\text { index }(\%)\end{array}$ \\
\hline L1F1 & $70.01 \mathrm{ef}$ & $12.60 \mathrm{~h}$ & $9.60 \mathrm{f}$ & $17.73 \mathrm{f}$ & $99.80 \mathrm{e}$ & $23.70 \mathrm{bcde}$ & $20.13 b$ & $16.90 \mathrm{~d}$ & $1.27 \mathrm{~h}$ & $1.913 \mathrm{~d}$ & $40.03 \mathrm{ef}$ \\
\hline L1F2 & 71.74de & $17.54 \mathrm{f}$ & $14.80 \mathrm{~cd}$ & $19.97 \mathrm{cde}$ & $121.2 \mathrm{~cd}$ & $26.13 b$ & $13.93 \mathrm{ef}$ & $18.53 b c$ & $2.55 \mathrm{~d}$ & $2.880 \mathrm{c}$ & $46.98 \mathrm{ab}$ \\
\hline L1F3 & $73.28 \mathrm{cde}$ & $18.31 \mathrm{ef}$ & $17.50 \mathrm{~b}$ & $20.73 b c$ & $119.3 d$ & $31.20 \mathrm{a}$ & $23.80 \mathrm{a}$ & $18.30 \mathrm{c}$ & $2.35 \mathrm{e}$ & $2.940 \mathrm{c}$ & $44.44 \mathrm{bcd}$ \\
\hline L2F1 & $71.61 \mathrm{de}$ & $14.92 \mathrm{~g}$ & $11.27 \mathrm{ef}$ & $18.13 \mathrm{ef}$ & $99.63 \mathrm{e}$ & $21.77 \mathrm{de}$ & $17.00 \mathrm{c}$ & $16.97 \mathrm{~d}$ & $1.49 \mathrm{~g}$ & $2.010 \mathrm{~d}$ & $42.71 \mathrm{de}$ \\
\hline $\mathrm{L} 2 \mathrm{~F} 2$ & $77.05 \mathrm{abc}$ & $20.21 \mathrm{de}$ & $18.30 \mathrm{~b}$ & $20.77 b c$ & $120.0 \mathrm{~d}$ & $21.53 \mathrm{de}$ & 13.7 & $18.43 \mathrm{bc}$ & $2.91 \mathrm{c}$ & $3.543 b$ & $45.09 \mathrm{abcd}$ \\
\hline $\mathrm{L} 2 \mathrm{~F} 3$ & $79.05 \mathrm{ab}$ & $22.77 \mathrm{c}$ & $18.30 \mathrm{~b}$ & $21.50 \mathrm{bc}$ & $117.8 \mathrm{~d}$ & $25.27 b c$ & $16.67 \mathrm{~cd}$ & $18.20 \mathrm{c}$ & $2.81 \mathrm{c}$ & $3.570 \mathrm{~b}$ & $44.10 \mathrm{~cd}$ \\
\hline L3F1 & $68.38 \mathrm{ef}$ & $14.80 \mathrm{~g}$ & $11.83 \mathrm{e}$ & $19.67 \mathrm{cde}$ & $103.9 \mathrm{e}$ & $23.10 \mathrm{cde}$ & $15.20 \mathrm{cde}$ & $17.10 \mathrm{~d}$ & $1.72 \mathrm{f}$ & $2.743 \mathrm{c}$ & \\
\hline L3F2 & $76.32 \mathrm{bcd}$ & $21.51 \mathrm{~cd}$ & $16.70 \mathrm{bc}$ & $21.03 \mathrm{bc}$ & $126.5 \mathrm{~b}$ & $18.23 \mathrm{f}$ & $12.03 \mathrm{fg}$ & $18.80 \mathrm{~b}$ & $3.27 b$ & $3.783 \mathrm{a}$ & $47.42 \mathrm{a}$ \\
\hline L3F3 & $80.94 \mathrm{ab}$ & $27.02 \mathrm{a}$ & 17. & & 126 & 21. & 14.8 & $18.20 \mathrm{c}$ & $3.13 \mathrm{~b}$ & $50 \mathrm{a}$ & 44.9 \\
\hline L4F1 & 6 & $15.15 \mathrm{~g}$ & 14. & 18.8 & 10 & 24.0 & & $17.07 \mathrm{~d}$ & $1.847 \mathrm{f}$ & & $72 \mathrm{f}$ \\
\hline L4F2 & $3.57 \mathrm{ab}$ & $23.55 \mathrm{bc}$ & & 25. & 136 & & 10.5 & $19.93 \mathrm{a}$ & $3.59 \mathrm{a}$ & $30 \mathrm{a}$ & $46.31 \mathrm{abc}$ \\
\hline L4F3 & $81.59 \mathrm{a}$ & $25.29 \mathrm{ab}$ & $15.00 \mathrm{~cd}$ & $20.63 \mathrm{bcd}$ & $125.8 b c$ & $21.87 \mathrm{de}$ & $14.20 \mathrm{def}$ & $18.60 \mathrm{bc}$ & $3.26 \mathrm{~b}$ & $3.867 \mathrm{a}$ & 45.79abc \\
\hline $\mathrm{CV}(\%)$ & 3.89 & 6.53 & 7.50 & & 2.65 & 6.84 & 9.90 & 1.37 & 3.72 & 3.89 & 3.79 \\
\hline LSD & 4.98 & 2.16 & & 1.899 & 5.24 & 2.65 & 2.60 & 0.42 & 0.16 & 0.21 & 2.81 \\
\hline Sig level & $* *$ & $* *$ & $* *$ & $* *$ & $* *$ & $* *$ & $* *$ & $* *$ & $* *$ & $* *$ & \\
\hline
\end{tabular}

In a column, means followed by common letters are not significantly different from each other at $5 \%$ \& $1 \%$ level of probability according to DMRT. $*=$ significant at $5 \%$ level, $* *=$ significant at $1 \%$ level. $\mathrm{L} 1=$ lime $0 \mathrm{t} \mathrm{ha}^{-1}, \mathrm{~L} 2=\operatorname{lime} 0.5 \mathrm{t} \mathrm{ha}{ }^{-1}, \mathrm{~L} 3=\operatorname{lime} 1.0 \mathrm{t}$ $\mathrm{ha}^{-1} \mathrm{~L} 4=$ lime $1.5 \mathrm{t} \mathrm{ha}^{-1}$. F1 = fertilizer $0 \mathrm{t} \mathrm{ha}^{-1}, \mathrm{~F} 2=$ fertilizer $(F Y M) 10 \mathrm{t} \mathrm{ha}^{-1}$, F3 = fertilizer (chemical) 100-30-42-4-3-0.4 kg ha ${ }^{-1}$ of N-P-K-Ca-S-Zn. 
The 1000-grain weight of varied significantly due to application of manures and fertilizers. The 1000-grain weight ranged from $17.01 \mathrm{~g}$ to $18.33 \mathrm{~g}$. The highest value was noted in $F_{2}$ treatment and the lowest 1000grain weight was noticed in the treatments $F_{1}$. Fertilizer application exerted increasing effect on grain weight as compared to the manures. Ganajzni et al. (2001) recorded greater 1000-grain weight in the fertilizer applied plot than the control plot. Lawal and Lawal, (2002) observed that increasing levels of nitrogen significantly increased 1000 -grain weight up to $80 \mathrm{~kg} \mathrm{~N}$ $\mathrm{ha}^{-1}$.

Interaction effect between lime and fertilizer management in BRRI dhan50 on 1000-grain weight was found significant at $1 \%$ level of probability (Table 4). The maximum 1000-grain weight $(19.93 \mathrm{~g})$ was recorded from the combination of $\mathrm{L}_{4} \mathrm{~F}_{2}$ and minimum 1000-grain weight was found $(16.90 \mathrm{~g})$ from combination of $\mathrm{L}_{1} \mathrm{~F}_{1}$ (Table 4). Hoque et al. (2016) and Mondal et al. (1990) recorded an increase of 1000-grain weight of rice from the application of organic manures.

\section{Grain yield}

The mean effect of lime irrespective of fertilizer management on grain yield is presented in Table 1. It was observed that levels of lime significantly affected grain yield (Table 2). The highest grain yield (2.90 tha $\left.{ }^{1}\right)$ was recorded in the treatment $\mathrm{L}_{4}$ where lime was applied @ $1.50 \mathrm{t} \mathrm{ha}^{-1}$. On the other hand, the lowest grain yield $\left(2.06 \mathrm{t} \mathrm{ha}^{-1}\right)$ was recorded in treatment $\mathrm{L}_{1}$ (control). Dixit et al. (1995) found significantly higher grain yield in rice due to lime application over control. In this study, the maximum grain yield in $\mathrm{L}_{4}$ was contributed by higher number of effective tiller, spikelets panicle ${ }^{-1}$ and 1000-grain weight. Application of lime increased crop yields and addition of lime provide yield increases of rice by $35 \%$ as direct and $31 \%$ as residual effect over no lime application (control) has been reported elsewhere. Such yield increase due to liming has also been reported on rice (Caires et al., 2008; Ernani et al., 2002). Liming increases soil $\mathrm{pH}$ and reduces soil acidity (Murphy and Sims, 2012). Such reasons for increasing crop yields by liming have also been suggested by many researchers (Venkatesh et al., 2002; Cifu et al., 2004; Costa and Rosolem, 2007).

It was observed that there were significant differences in grain yields among the fertilizer management treatment (Table 3). The highest grain yield $\left(3.55 \mathrm{t} \mathrm{ha}^{-1}\right)$ was recorded in treatment $\left(\mathrm{F}_{3}\right)$. On the other hand, the lowest grain yield $\left(2.40 \mathrm{t} \mathrm{ha}^{-1}\right)$ was recorded in treatment $\mathrm{F}_{1}$ (control). Singh and Jain (2000) stated that high rate of NPK significantly increased grain yield. Thakur et al. (1997) observed that application of fertilizer at optimum rate increased the number of effective tillershill ${ }^{-1}$ and filled grains panicle ${ }^{-1}$ that resulted in higher grain yield of rice than control.
The effect of interaction of lime and fertilizer treatments on the grain yield was significant at $1 \%$ level of probability (Table 4). The highest grain yield was recorded $\left(3.59 \mathrm{t} \mathrm{ha}^{-1}\right)$ from the combination of $\mathrm{L}_{4} \mathrm{~F}_{2}$. The lowest grain yield $\left(1.27 \mathrm{t} \mathrm{ha}^{-1}\right)$ was observed from the combination of $\mathrm{L}_{1} \mathrm{~F}_{1}$. It was observed from the results presented in Table 3 that the yields of $0 \mathrm{t} \mathrm{limeha}^{-1}$ with 0 $\mathrm{kg}$ fertilizer was the least yield and with increased level of lime along with fertilizer either chemical or manures increased yields.

\section{Straw yield}

There was significant difference in straw yields among the doses of liming (Table 2). The highest straw yield $\left(3.54 \mathrm{t} \mathrm{ha}^{-1}\right)$ was recorded in treatment L4 where lime was applied @ $1.50 \mathrm{t} \mathrm{ha}^{-1}$. On the other hand, the lowest straw yield $\left(2.578 \mathrm{t} \mathrm{ha}^{-1}\right)$ was recorded in treatment $\mathrm{L}_{1}$ (control). The straw yields of rice increased with the application of lime. Such yield increase due to liming has also been reported on rice (Caires et al., 2008; Ernani et al., 2002). Liming increases soil $\mathrm{pH}$ and reduces soil acidity ultimately increasing straw yields (Murphy and Sims, 2012). Such reasons for increasing straw yields by liming have also been suggested by many researchers (Warman et al., 1996; Tsakelidou, 2000; Tang et al., 2003).

Fertilizer treatments irrespective of lime rate affected straw yield significantly (Table 3 ). The highest straw yield $\left(3.56 \mathrm{tha}^{-1}\right)$ was found in fertilizer treatment $\left(\mathrm{F}_{3}\right)$. The lowest straw yield $\left(2.40 \mathrm{t} \mathrm{ha}^{-1}\right)$ was recorded in control $\left(\mathrm{F}_{1}\right)$. Hasanuzzaman et al. (2010) reported that straw yield increased with increasing fertilizer levels in rice. Kumar et al. (1996) observed that increasing levels of $\mathrm{N}$ significantly increased the dry matter and straw yields increased with increasing levels of NPK fertilizer and other micro nutrients.

The effect of interaction of lime and fertilizer on the straw yield was significant at $1 \%$ level of probability (Table 4). The highest straw yield was recorded (3.87 t $h^{-1}$ ) from combination $\mathrm{L}_{4} \mathrm{~F}_{3}$ (Table 3 ). The lowest straw yield $\left(1.91 \mathrm{t} \mathrm{ha}^{-1}\right)$ was observed from the combination $\mathrm{L}_{1} \mathrm{~F}_{1}$ (Table 4).

\section{Harvest index}

The mean data revealed that no significant difference between the harvest indices of the doses of lime rate was occurred. However, application of lime at the rate of $0.50 \mathrm{t} \mathrm{ha}^{-1}\left(\mathrm{~L}_{2}\right)$ produced the highest harvest index (43.97 $\%)$ which was similar to treatment $\mathrm{L}_{3}(43.63 \%)$. The lowest harvest index $(43.61 \%)$ was found in the highest application of dolochun at the rate of $1.50 \mathrm{tha}^{-1}\left(\mathrm{~L}_{4}\right)$.

Data revealed that a significant difference between the harvest indexes of the doses of fertilizer was occurred. Application of cow dung at the rate of $10 \mathrm{t} \mathrm{ha}^{-1}\left(\mathrm{~F}_{2}\right)$ produced the highest harvest index $(46.45 \%)$ which was similar to treatments $\mathrm{F}_{3}(44.81 \%)$. The lowest harvest index $(40.01 \%)$ was found in the control $\left(\mathrm{F}_{1}\right)$. 
The interaction effect of lime and fertilizer treatment on Banglamoti rice showed that the harvest index was greatly influenced at $5 \%$ level of probability. The highest harvest index $(47.42 \%)$ was recorded from combination $\mathrm{L}_{3} \mathrm{~F}_{2}$. The lowest harvest index $(38.58 \%)$ ) was observed from the combination $\mathrm{L}_{3} \mathrm{~F}_{1}$ (Table 3 ).

\section{Effect of lime, manures and fertilizer on soil} characteristics

Application of lime, manures and fertilizers caused an increasing effect on the $\mathrm{pH}$ of the post-harvest soils (Table 1). The $\mathrm{pH}$ value of the post-harvest soils ranged from 5.2 to 6.0 as compared to the initial $\mathrm{pH}$ value of 5.2 (Table 1). All the treatments recorded higher soil $\mathrm{pH}$ value as compared to initial soil. The lowest value of $\mathrm{pH}$ was observed in $\mathrm{L}_{2}$ and the highest value was recorded in $\mathrm{L}_{4}$. Lime reduced soil acidity by changing some of the $\mathrm{H}^{+}$ions into water and carbon dioxide $\left(\mathrm{CO}_{2}\right)$. The results support previous findings showing that lime was effective in alleviating soil acidity (Caireset al. 2005; Venkatesh et al. 2002; Chang and Sung 2004; Cifuet al. 2004).

The organic matter content of the post-harvest soils slightly increases due to application of fertilizers while results were reverse in most cases when manures were applied (Table 1). Organic matter content of the postharvest soils varied from 1.85 to $2 \%$ and the value for the initial soil was $1.85 \%$ (Table 1). It was observed that organic matter content tended to increase in soils treated with organic manures. The highest value of organic matter content was observed in the treatment $\mathrm{F}_{2}$ and (control) recorded the lowest value. Zhang et al. (1996) showed that the combined application of organic manures and chemical fertilizers increased organic matter content in soil.

The total $\mathrm{N}$ content in the post-harvest soils varied from $0.11 \%$ to $0.13 \%$ (Table 1). A slight increase in total $\mathrm{N}$ content was noted in all the soils treated with lime and cow dung while the treatments control showed a slight decrease in $\mathrm{N}$ value as compared to the initial soil. The results indicated that application of manures exerted an increasing effect on the total $\mathrm{N}$ content of the postharvest soils. Gao and Chang (1996) reported that the application of organic manures increased the total $\mathrm{N}$ concentration in soil.

The results in Table lindicated that the use of lime, manures and fertilizer had a considerable change in available $\mathrm{P}$ content of the post-harvest soils due to different treatment. Available $\mathrm{P}$ content in the postharvest soils ranged from 26 to $81 \mathrm{ppm}$. The highest value was recorded in the treatment $\mathrm{L}_{4}$ and lowest available $\mathrm{P}$ content in the post-harvest soil was $26 \mathrm{ppm}$ in treatment $\mathrm{L}_{2}$. The $\mathrm{P}$ availability increased with increasing rats of lime $(\mathrm{CaCO} 3)$ application up to @ $1.50 \mathrm{tha}^{-1}$ for the experimental field. With the lower rate of lime (@0.50 t ha ${ }^{-1}$ ), the $\mathrm{P}$ availability increased substantially. On the other hand, with the higher rate of lime(@1.50 t ha ${ }^{-1}$ ), the $\mathrm{P}$ availability decreased considerably. The $\mathrm{P}$ availability in soil was highly $\mathrm{pH}-$ dependent. In acid soil, the $\mathrm{p}$ availability decreased due to precipitation of $\mathrm{P}$ with insoluble $\mathrm{Fe}$ - and $\mathrm{Al}-$ Phosphates. This result agrees well with other findings, indicating that liming improves soil extracted $\mathrm{P}$ availability (Caires et al.,, 2005; Haynes, 1982; The et al. 2006).

Exchangeable $\mathrm{K}$ content in the post-harvest soils ranged from 0.16 to $0.19 \mathrm{me} / 100 \mathrm{~g}$ soil (Table 1). Exchangeable $\mathrm{K}$ contents in the post- harvest soils were influenced due to the application of lime, manures and fertilizers. The highest value of exchangeable $\mathrm{K} 0.19$ was found in the $\mathrm{F}_{2}$ (cow dung) treatment while the treatment $\mathrm{L}_{4}$ (lime) recorded the lowest value. Results also indicated that exchangeable $\mathrm{K}$ content was higher in soils treated with manures compared to those treated with lime (Table 1). Singh and Jain (2000) observed that K availability as increased with the increasing application of organic matter.

Available sulphur contents in the post-harvest soils were influenced due to use of different treatments (Table 1). Sulphur contents in the post-harvest soils ranged from 29 to $39 \mathrm{ppm}$, whereas it was $22 \mathrm{ppm}$ in the initial. The highest available $\mathrm{S}$ content was recorded $39 \mathrm{ppm}$ in chemical fertilizer treatment and the lowest value was recorded in (cow dung) $\mathrm{F}_{2}$ treatment (Table 1). Ganeshamurthy and Reddy (2000) also reported that application of cow dung increased the available $\mathrm{S}$ in the post-harvest soils.

Available zinc contents in the post-harvest soils are presented in the Table 1. Available zinc contents in the post-harvest soils were influenced due to use of different treatments. Available zinc contents in the post-harvest soils ranged from 0.98 to $3.11 \mathrm{ppm}$. The zinc content in the initial soil was $0.98 \mathrm{ppm}$. The highest available $\mathrm{Zn}$ content was recorded in the $3.11 \mathrm{ppm}$ (chemical fertilizer) treatment and the lowest value was recorded in control.

\section{Conclusion}

From the study, it can be concluded that yield performance of BRRI dhan50 rice was maximum when it was cultivated by applying lime@1.50 t ha ${ }^{-1}$ in combination with organic fertilizer FYM @ $10 \mathrm{t} \mathrm{ha}^{-1}$ in acid soils. Dolochun $\left(\mathrm{CaCO}_{3}, \mathrm{MgCO}_{3}\right)$ as source of lime can be used to reduce the acidity level and raising $\mathrm{pH}$ level of soils. Side by side, organic fertilizers (FYM @ $10 \mathrm{tha}^{-1}$ ) is also needed to apply for optimum supply of plant nutrients.

\section{Acknowledgements}

We are indebted to University Grants Commission, Bangladesh for the research work grant (Grant no. UGC/RP/Agri.6(78)/2009-10). We are grateful to Soil Resources Development Institute, Sylhet-3100, Bangladesh for analysis of soil samples. 


\section{References}

Alfaons, J.P.S., Esther, C.H.B.T.L., Martijn van der, A., Leon, P.M.L. and Jan G.M.R. 2008. Decreasing the abundance of Juncuseffusus on former agricultural lands with noncalcareous sandy soils: possible effects of liming and soil removal. Restoration Ecol. 16 (2): 240-248. https://doi.org/10.1111/j.1526-100X.2007.00267.x

Azad, A.K., Samanta, S.C., Kashein, M.A. and Islam, M.T. 1995.Response of BR10 rice to different levels of nitrogen and spacing. Bangladesh J. Sci. Ind. Res. 30: 31-38.

Banerjee, D.G. and Das, B. 2001.Different forms of soil acidity and lime requirement of some acid soils of West Bengal. Indian Agric. 45 (3 \& 4): 209-213.

BINA. 2009. Effect of nitrogen and potassium on growth and yield of fine grain rice. Annual Report of 2008-09, Bangladesh Institute of Nuclear Agriculture (BINA), Mymensingh.

Caires, E.F., Alleoni, L.R.F., Cambri, M.A. and Barth G. 2005. Surface application of lime amelioration sub-soil acidity and improves root growth and yield of Wheat in an acid soil under no-till system Sci. Agricola. 63: 502-509. https://doi.org/10.1590/S0103-90162006000500013

Caires, E.F., Garhuio, F.J., Churka, S., Barth, G. and Correa, J.C.L. 2008. Effects of Soil Acidity Amelioration by Surface Liming on No-till corn, soybean and wheat root growth and yield Europ. J. Agron. 28: 57-64. https://doi.org/10.1016/j.eja.2007.05.002

Chang, C.S. and Sung, J.M. 2004. Nutrient uptake and yield responses of peanuts and rice to lime and fused magnesium phosphate in an acid soil. Field Crops Res., 89: 319-325. https://doi.org/10.1016/j.fcr.2004.02.012

Chopra, N.K. and Chopra, N. 2004. Seed yield and quality of Pusa-44 rice as influenced by nitrogen fertilizer and row spacing. Indian J. Agric. Sd. 74: 144-147.

Cifu, M., Xiaonan, L., Zhihong, C., Zhhengyi, H. and Wanzhu, M 2004. Long-term effect of lime application on soil acidity and crop yields on a red soil in Central Zhejiang. Plant and Soil, 265: 10 1-109.

Costa, A. and Rosolem, C.A. 2007. Liming in the translation to no-till under a wheat soybean rotation. Soil and Tillage Res. 97: 207-217. https://doi.org/10.1016/j.still.2007.09.014

Coventry, D.R., Slattery, W.J., Burnett, V.F. and Ganning, G.W. 1997. Longevity of wheat yield response to lime in south-eastern Australia. Australian J. Expt. Agri. 37(5): 571-575. https://doi.org/10.1071/EA96146

Dixit, S.P., Prasad, R.N., Rai, R.N. and Sharma, P.K. 1995. Effect of lime and potassium on lime and phosphate potential and crop yield on an Alfisol Indian Soc. Soil sci. 43(1): 78-80.

Ernani, P.R., Bayer, C. and Maestri, L. 2002. Corn yield as affected by liming and tillage system on an acid Brazilian Oxisol. Agron. J. 94:305-309. https://doi.org/10.2134/ agronj2002.0305

FAO. 2017, Food and agricultural organization of the united nations, FAOSTAT:http://www.fao.org/faostat/en/\#data/QC

FAO, 2008, Production Year Book of 2008, No. 67.Published by Food and Agriculture Organization (FAO), Rome, Italy. p. 54

Ganeshamurthy, A.N.and Reddy, K.S. 2000. Effect of integrated use of farmyard manure and sulphur in a soybean and wheat cropping system on nodulation, dry matter production and chlorophyll content of soybean on swell-shrink soils in central India. J. Agron and Crop Sci. 185(2): 91-97. https://doi.org/10.1046/j.1439-037x.2000.00403.x

Gao, G. and Chang, C. 1996. Changes in CEC and particle size distribution of soils associated with long-term annual application of cattle feed lot manure. Soil Sci. 161(2): 115120. https://doi.org/10.1097/00010694-199602000-00006

Ganajani, A., Hoglo,Y. and Angadi, V.V. 2001. Effect of planting dates and nitrogen levels on the grain yield of aromatic rice. Indian J. Agric. Sd. 34: 758-760.

Gomez, K.A. and Gomez, A. 1984. Statistical procedure for agricultural research. 2ndedn. John Wiley and Sons Inc. New York

Gowariker, V., Krishnamurthy, V.N., Gowariker, S., Dhanorkar, M. and Paranjape, K. 2009. The Fertilizer Encyclopedia. John
Wiley and Sons, Inc. Publication, Hoboken, New Jersey, USA.

Haque,M.R. and Jahiniddin, M. 1994. Effects of single and multiple applications of sulphur and zinc on a continuous rice cropping pattern. Indian J. Agril. Res. 28: 9-14.

Hasanuzzaman, M., Ahamed, K.U., Rahmatullah, N.M., Akhter, N., Nahar, K. and Rahman, M.L. 2010. Plant growth characters and productivity of wetland rice (Oryza sativa L.) as affected by application of different manures. Emir. J. Food Agric. 22 (1): 46-58.

Haynes, R.J. 1982. Effects of liming on phosphate availability in acid soils. Plant and Soil, 68(3): 289-308. https://doi.org/ 10.1007/BF02197935

Herve, D.S., Annih, M.G., Kenyi, M.D. and Cristopher, S. 2017. Effect of different doses of NPK fertilizer on the growth and yield of rice in Ndop, North West of Cameroon. African J. Agril. Res. 12(15): 1244-1252.

Hoque, M., Rahman, M.Z., Hasan, A.K. and Haque, M.M. 2016. Optimizing fertilizer rate for Banglamati (BRRI dhan50) rice in eastern Surma-Kushiyara floodplain. Int. J. Sustain. Crop Prod. 11(2):1-3.

Hoque, M., Yeasmin, F. and Haque, M.M. 2013. Screening suitable aromatic rice variety for Sylhet region of Bangladesh. Bangladesh J. Prog. Sci. \& Tech, 11(1): 041-044.

Hossain, M.M. and Sattar, M.A. 2002. Physical and chemical properties of some selected soils of Bangladesh. Online J. Biol. Sci. 2(2): 79-83. https://doi.org/10.3923/ jbs.2002.79.83

Huang, X., Wei, X., Sang, T., Zhao, Q., Feng, Q., Zhao, Y., Li, C., Zhu, C. and Lu,L.,et al. 2010 Genome-wide association studies of 14 agronomic traits in rice landraces. Nat. Genet. 42: 961-967. https://doi.org/10.1038/ng.695 PMid:20972439

Islam, M.R. and Hossain, A. 1993. Influence of additive nutrients on the yield of BR 11 rice. Thai. J. Agril. Sci. 26: 195-199.

Karažija T., Čosić T., Lazarević B. and Horvat T., et al. 2015.Effect of organic fertilizers on soil chemical properties on vineyard calcareous soil. Agriculturae Conspectus Scientificus 80(2): 79-84.

Karim, Z., Miah, M.M.V. and Razia, S. 1994. Fertilizer in the national economy and sustainable environment. Asia Pacific Environ. Dev. 2: 48-67.

Kumar, M., Haque, M., Singh, S.B. and Pathak, S.K. 1996. Effect of graded levels of nitrogen on yield and quality of scented rice varieties in Southern alluvial Gangetic plants of Bihar. J. Appl. Biol. 6: 61-63.

Lawal, M.I. and Lawal, A.B. 2002. Influence of nitrogen rate and placement method on growth and yield of rice at Kadawa, Nigeria. Crop Res. 23(3): 403-411.

Maske, M.S., Chind, R.S. and Singh, B. 1997. Response of new rice varieties to N. Intl. Rice Res. Newsl. 22: 8-9.

Mohammad, T., Deva, W. and Ahmed, Z. 2002. Genetic variability of different plant and character in rice. Sarhad J. Agric., 18: 207-210.

Mondal, S.S., Joyararn, D. and Pradhan, B.K. 1990. Effect of fertilizer and farmyard manure on the yield and yield components of rice (Oryza sativa L.) Environ. Eco. 8(1): 223-226.

Moody, P.W., Aitken, R.L. and Dickson, T. 1995. Diagnosis of maize yield response to lime in some weathered acidic soils. In 'Plant-soil interactions at low $\mathrm{pH}$ Proceedings of the $3 \mathrm{rd}$ International Symposium on Plant-soil interactions at low pH. pp. 537-541.https://doi.org/10.1007/978-94-011 -0221$\underline{6} 82$

Muhammad, M., Babar, M.H. and Muhammad, T. 2005. Effect of nursery transplanting techniques and nitrogen levels of growth and yield tine grain rice (Basmati-2000). Pakistan J. Agric. Sd. 42; 21-24.

Murphy, P.N.C. and Sims, J.T.2012. Effects of Lime and Phosphorus Application on Phosphorus Runoff Risk. Water, Air, \& Soil Pollution. 2012; 223. 10.1007/s11270-012-1293-3. https://doi.org/10.1007/s11270-012-1293-3

Patiram, R.R.N. and Prasad, R.N. 1990. Effects of liming on aluminum yield wheat in acidic soil. J. Indian Soc. Soil Sci. 38: 719722. 
Rahman, G.K.M.M., Afrad, M.S.I. and Rahman, M.M.2014.Status of compost usage and its performance on vegetable production in Monga areas of Bangladesh. Int. J. Agril. Res. Innov. \& Tech. 4 (2): 22-28.

Reddy, C.H.B.R. and Subramanian, KS 2016. Synthesis and characterization of nano-amendment for effective remediation of soil acidity. Asian J. Soil. Sci., 11(1): 5157. https://doi.org/10.15740/HAS/AJSS/11.1/51-57

Scott, B.J., Conyers, M.K., Poilc, G.J. and Cullis, B.R. 1999. Reclamation and re-liming effects on soil properties and wheat yield. Aust. J. Exp. Agric. 39:849-856. https://doi.org/10.1071/EA99040

Scott, B.J., Fisher, J.A. and Cullis, B.R. 2001. Aluminum tolerant and lime increase wheat yield on the acidic soils of central and southern New South Wales. Aust. J. Exp. Agri. 41:523532. https://doi.org/10.1071/EA00038

Sekhar, B.P.S. and Reddy, G.M. 1982. Amino acid profiles in some scented rice varieties. Theor. Appl. Genet. 62:35-37. https://doi.org/10.1007/BF00276278 PMid:24270531

Singh, S. and Jain, M.C. 2000. Growth and yield response of traditional tall and improved semi-tall rice variety to moderate to moderate and higher nitrogen. Phosphorous and potassium levels. Indian J. Plant Physiol. 5: 38-46.

Slattery, W.J. and Conventry, D.R.1993. Response of wheat, triticale, barley and canola to lime on four soil types in south-eastern Victoria. Aust. J. Soil Res. 33:609-618.

Tang, C., Rene1, Z., Diatloff, E. and Gazey, C. 2003.Response of wheat and barley to liming on a sandy soil with subsoil acidity. Field Crop Res. 80: 235-244. https://doi.org/10.1016/S0378-4290(02)00192-2

Thakur, R.B., Jhan, A.K. and Sharma, R.P.R. 1997. Effect of levels and time of $\mathrm{K}$ application of potash on wetland rice. Intl.
Symp. On A decade of potassium research, 18-20 Nov, New Delhi, India. p. 138-140

The, C., Calba, H., Zonkeng,C., Ngonkeu, E.L.M., Adetimirin, V.O., Mafouasson, H.A., Meka, S.S. and Horst, W.J. 2006. Responses of maize grain yield changes in acid soil characteristics after soil amendments. Plant and Soil. 284: 45-57. https://doi.org/10.1007/s11104-006-0029-9

Tsakelidou, K. 2000. Effect of calcium carbonate as determined by lime requirement buffer $\mathrm{pH}$ methods on soil characteristics and yield of sorghum plants. Commun. Soil Sci. Plant Anal. $31(9,10): 1249-1260$

Venkatesh, M.S., Majumdar, B., Kunar, K. and Patiram. 2002. Effect of Phosphorus, FYM and lime on yield, P uptake by maize and forms of soil acidity in typichapludalf of Meghalaya, J. Indian Soc. Soil Sci. 50 (3): 254-258.

Wagh, R.G. and Thorat, S.T. 1988. Response of' rice var. R-24 to different times of application of nitrogen and plant densities in coastal soils. J. Indian Soc. Coastal Agril. Res. 6: 133137

Warman, P.R., Harnish, B. and Muizelaar, T. 1996. A Lime requirement test for maritime Canada, and response time and effect of liming source on soil $\mathrm{pH}$. Commun. Soil Sci. Plant Anal. 27(5-8): 1427-1436. https://doi.org/10.1080/ 00103629609369643

Westermann, D.T. 1992. Lime effects on phosphorus availability in calcareous soil. Soil Sci. Soc. America J. 56(2): 489-494. https://doi.org/10.2136/sssaj1992.03615995005600020024x

Zhang,M.,Gu, H. and Peng, P. 1996. Study on combined application of organic and inorganic fertilizers in dry and poor red paddy soils. Res. Agric. Modernization. 17 (10): 41-44. 